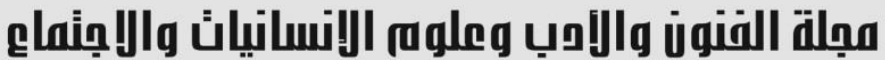

Journal of Arts, Literature, Humanities and Social Sciences www.jalhss.com

\section{The Law Applicable to The Arbitration Dispute}

\author{
Dr. Qais Khaleel Sallam Maaitah \\ Associate Professor of Commercial Law \\ Private Law Section - Faculty of Law - Applied Sciences University \\ Kingdom of Bahrain \\ Email: qais.maaitah@asu.edu.bh
}

\begin{abstract}
The aim of the arbitrators is to adjudicate the dispute away from traditional procedural constraints with its complex formalities and a long time before the courts. One of the basic rules on which the arbitration system was based was the freedom of the parties at all stages of arbitration to choose arbitration as an alternative dispute resolution route, by selecting the law applicable to arbitration proceedings or the law applicable to the subject matter of the dispute and by the execution of the arbitral award.

The role of the arbitral tribunal stems from the agreement of the parties to the arbitration dispute and from the regulations in the arbitration contract or the arbitration document requiring the parties to the arbitration to sign an arbitration document at the commencement of the proceedings, and the proceedings begin since a party to the arbitration dispute has indicated its willingness to settle the dispute by arbitration. In other words, the request for arbitration shall be made until the award is finalized.
\end{abstract}

Keywords: Arbitration, arbitrator, applicable law, arbitration proceedings, subject matter of dispute. 


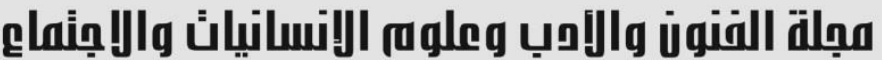

Journal of Arts, Literature, Humanities and Social Sciences www.jalhss.com

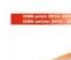
unlllo iuiall allan (1)

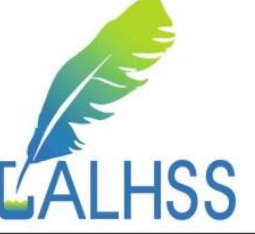

\section{Introduction:}

The authority of the arbitrator stems from the agreement and the agreement contained in the arbitration contract or the arbitration document in the regulations that require the parties to sign an arbitration document at the beginning of the court proceedings, as is the system in the arbitration of the International Chamber of Commerce in Paris. Sometimes the arbitral contract separates the authorities of the arbitrators, and sometimes refers the arbitral contract to an arbitral system such as the rules of UNCITRAL, which shall be the authority of the arbitrators provided for in these arbitral regulations and shall be derived from the authorities of the parties. The arbitrators shall be given the authorities to nominate experts, to appoint trial sessions, to investigate evidence and to examine the subject of the dispute ... Etc.

The law also gives the courts enormous coercive authorities, enabling them to enforce their judgments, but the arbitral tribunal does not have such authorities, and the parties cannot give the arbitral tribunal coercive authorities over the funds, but some laws (such as the English Arbitration Act) are expanding the exercise of its authorities to the arbitral tribunal.

The best way to identify the court's arbitral authorities is to return to the arbitration contract, then to the law applicable to the arbitration contract, finally to return to the law applicable to the arbitral tribunal proceedings, and to refer either to an arbitral tribunal or an arbitral tribunal system such as the UNCITRAL system.

If we then return to the law applicable to the arbitration contract governing the validity, effect and interpretation of the arbitration contract, this law can give the arbitrators authorities, and can withhold and reduce their authorities.

\section{Importance of Study:}

The issue of law, which is applicable to contracts in general, is difficult and complex, and this difficulty is evident when this issue is raised before the international arbitrator in the international commercial arbitration litigation. The use of arbitration by parties of international nationalities to arbitration gives them the freedom to follow international rules. Certain, and by choosing the applicable law in order to govern their disputes, especially since there are no uniform rules of arbitration (Abderrahmane, Huda Muhammad, p. 229-230).

It is clear that in the event that the arbitrators in a relationship agree to resolve disputes arising from such a relationship by arbitration, Any dispute between them would lead to the erosion of arbitral proceedings, which would begin with the formation of the arbitral tribunal and would continue only with a judgment in the arbitral dispute in accordance with certain procedures and rules established by the will of the parties and determined by law.

At first glance, it may be envisaged that the rules and provisions of a single law will be applied at all stages of the arbitration dispute and arbitration proceedings, but this is not necessary. This is due to the will of the parties or the arbitral tribunal. Considerations in the choice of the law applicable to arbitral proceedings may differ from those taken into account and that force them to choose the law applicable to the 


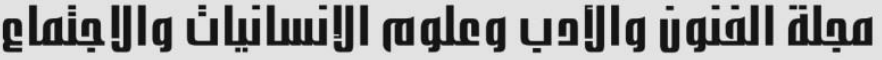 \\ Journal of Arts, Literature, Humanities and Social Sciences www.jalhss.com \\ Volume (54) July 2020 \\ العدد (54) يوليو 2020}

subject matter of the dispute, so the two laws must not be confused.

The main difference between the laws is the duty to apply to arbitral proceedings and that applicable to the subject matter of the dispute. That the law applicable to the proceedings is not an end in itself, but a means used to reach a particular purpose of demonstrating the disputed aspects of the truth among the arbitrators before the arbitrators who adjudicate it, While the law governing the subject of the dispute embodies the rights and obligations of the arbitrators to define and define these rights and obligations, it is an end in itself.

The issue of applicable law in the arbitration case in general is of great importance, as procedural rules govern the conduct of litigation from procedures such as dates, exchange of notes and documents, hearing witnesses, causing and filing of the judgement, etc., and there is no doubt that the observance of these rules in a manner It is true that a valid arbitration judgement that can be recognized and implemented would be reached, and on the contrary, a violation of these rules would open the door wide open to challenging the arbitral award of nullity and refusing to recognize it and implement it.

As for the law applicable to the subject of the dispute, the future of the dispute is dependent on its determination of the rules and provisions in which the rights, obligations and fate of each party to the arbitral dispute will be determined.

In view of the importance of the determination of the law applicable to the subject matter of the dispute, the various legal regimes for arbitration have paid much attention to the legal regulation of the arbitration system in general and the determination of the law applicable to the subject matter of the dispute in particular.

The extrapolation of arbitration laws and regulations makes clear that there are mostly common rules, and that most of them have an important legal principle of the freedom of the parties to choose the law governing the proceedings and, moreover, the subject of the dispute. The search for the law governing the procedure or that governing the subject matter of the dispute day by day emphasizes the international nature of this system as an independent judiciary of international trade, and it is now almost universally enjoyed by an independent law governed by it.

\section{Study problem:}

In view of the broad authorities of the arbitrator, it is necessary to clarify those authorities which he collects, since the private independent nature of arbitration gives its results to the arbitrators' authorities. Sometimes they are expanded, sometimes to narrow their limits, and in the same way the judicial data are obstructing the freedom of the arbitrator and the parties to this organization, as well as the solutions decided by arbitration. For these reasons, the extent of the arbitrators' authorities must be determined, particularly in the choice of the applicable law, whether in arbitral proceedings or in the subject of the dispute. 


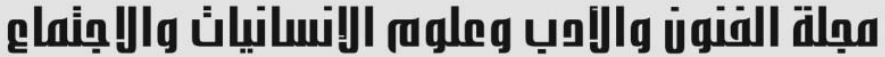

Journal of Arts, Literature, Humanities and Social Sciences www.jalhss.com

\section{Curriculum:}

The study followed the descriptive and analytical approaches by reviewing the texts of the UNCITRAL Municipal Model Law of the United Nations Commission on International Trade Law, dated 21 July 1985, as amended in 2006, adopted by the Bahraini Arbitration Act No. 9 of $2015^{(1)}$; Compared with other arbitration legislation and regulations.

\section{Study Plan:}

In the light of the above, the authority of the arbitrator in this regard is established in two matters: The law is applicable to arbitration proceedings, and the second is that governing the dispute, so the study requires that both matters be identified by two, respectively.

\section{The arbitrator's authority to choose the applicable law to arbitration proceedings}

This authority may be adapted in view of the arbitration contract as the right of the arbitrator; In view of the arbitration agreement as an obligation based on its jurisdiction and this authority finds its origin in the law, to the extent and to the extent that the parties may not agree to exempt the arbitrator from following the procedures set forth in the pleadings Act and in effect before the courts of the State, In particular, the procedures contained in the arbitration law and those related to its lack of authority of order, as well as those related to the fundamental principles of litigation, and in this context the arbitrator is free to regulate arbitral proceedings, including the determination of the law applicable to arbitral proceedings, if, of course, the parties do not agree on a particular law. In addition to choosing or supplementing the rules of procedure, taking into account and respecting the fundamental principles of litigation. The issue of the determination of the law applicable to arbitral proceedings is one of the most complex issues facing arbitration in private international law, considering that it touches closely many considerations that sometimes run counter to each other, On the one hand, the independence of the arbitration clause grants the parties to the dispute to a different choice of law that should govern this contract in accordance with the conflicts of laws in private international law (Ibrahim, Ibrahim Ahmed, 1997, p. 131), and the failure to observe or violate arbitration proceedings entails invalidity of the judgment and refusal to recognize or enforce it (Alhdad, Hfeeza al-Sayyed, 1997, p. 191).

We will review this in three sections as follows.

\subsection{The liability agreement on the determination of the law applicable to arbitral proceedings}

In view of the fact that arbitration is based in essence on the agreement of the arbitrators, it is in no way possible to deny the role of the arbitrators' will to determine its procedures, but this will may be lagging or imperfect, so technical controls to be 


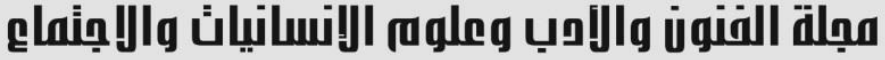 \\ Journal of Arts, Literature, Humanities and Social Sciences www.jalhss.com \\ Volume (54) July 2020 \\ العدد (54) يوليو 2020}

used in determining the law applicable to arbitral proceedings must be examined. These include the use of the Arbitration Headquarters Act or the Arbitration Board (Abu Al-Ala, Abu Al-Ala Ali, N.D, p.11).

The independence of the arbitration clause and whether an item in the contract or an independent participation of the parties to the dispute allows the choice of any law that they consent to the arbitration proceedings, irrespective of any link between it and the contract in question (Radwan, Abu Zeid, 1981, 83-84).

While it is envisaged that these procedures will be subject to the same law as the subject of the dispute, they may be subject to a different law, the law governing the proceedings must not be confused with that governing the subject (Ibrahim, Ibrahim Ahmed, 1997, p. 132).

She referred to those segments, for example, the Amman Arab Convention for Commercial Arbitration of 1987, which stipulated that the arbitral tribunal was subject in its settlement to the law of the express or implied contracting parties' will (art. 21/1), which was consistent with the general principles of commercial arbitration, particularly international arbitration (Haddad, Hamza, 1989, p. 31).

If they do not agree, the Commission shall apply the provisions of the law most relevant to the subject matter of the dispute, but this shall require the observance of the rules of established international commercial customs (art. 21/1).

\section{2: The positive role of the parties in determining a form or rules of procedure followed by the arbitrator}

In this positive role, the parties to the dispute can codify detailed procedural rules governing this dispute before the arbitral tribunal that is constituted for this purpose.

In other words, adversaries can regulate the conduct of a dispute according to procedural rules from the creation or creation of their will, or invoke procedural rules that would constitute a mixed structure of many arbitration rules, so that they would become a new component that is not connected with such regulations, such rules would have been derived from international arbitration regulations. For example, the United Nations Regulations of 15 September 1976, the Regulations of International Arbitration Centers and bodies, or the Arbitration Centers or Courts of a National character, such as the Rules of Procedure for proceedings before the arbitral tribunal, its place, the time for submission of documents, how to hear witnesses, conduct investigations, use of experts and the language in which arbitration is conducted; Permission to attend, response of arbitrators, interruption of the course of the antagonism, resumption of the proceedings, the causing or non-causing of decisions, their admissibility or non-appeal, and other matters of procedure.

This meaning was clearly expressed in the European Geneva Convention on International Commercial Arbitration of 1961, in which article IV, paragraph 2, section III, and provides for the freedom of the parties to the arbitration agreement to determine the rules of procedure to be followed by the arbitrators.

Article V of the 1958 New York Convention allowed the refusal to recognize and implement an arbitral award because arbitration proceedings did not conform to the 


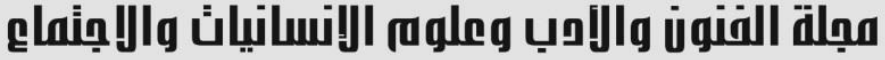 \\ Journal of Arts, Literature, Humanities and Social Sciences www.jalhss.com \\ Volume (54) July 2020 \\ العدد (54) يوليو 2020}

agreement of the parties, or to the law of the State in which arbitration took place in the absence of an agreement between the parties.

Nor does it imply the ability of the arbitrator to follow a procedure during the course of the conduct of the arbitration, but rather its authority to determine such proceedings in advance before the commencement of the arbitration proceedings.

The principle that arbitration procedures should be subject to the will of the parties was also endorsed by the Model Law on International Commercial Arbitration, which was adopted by the United Nations Commission on International Trade Law for 1985 and amended in 2006, article 19 of which states: "1. Subject to the provisions of this Act, the parties shall be free to agree on the procedures to be followed by the arbitral tribunal when proceeding with arbitration. 2. If there is no such agreement, the arbitral tribunal, taking into account the provisions of this law, shall proceed in arbitration in such manner as it deems appropriate, and the authority of the arbitral tribunal shall include a determination of the admissibility, relevance, usefulness and relevance of the evidence submitted."

\section{3: Freedom of choice for arbitrators or to supplement the rules of procedure for the conduct of the dispute}

If the rule that arbitration proceedings are subject to the will of the parties is not in doubt, the difficulty when there is no agreement on rules of procedure or their failure to refer to a law to be applied by the arbitrator in the proceedings, as well as in the case of insufficient procedures agreed upon by the parties, as noted by some jurisprudence (Ibrahim, Ibrahim Ahmed, 1997, p. 134) We cannot ask the arbitrator to prepare a full legal regulation of pleadings to complement the will of the parties. In such cases, the arbitrator will have broad authority in determining the rules that will govern the arbitration proceedings (Alrefeay, Ali Kazim). (N.D). P.44).

It seems clear that the arbitrator has wider authorities in this regard and is not even recognized by the State judiciary, and can therefore determine the procedures to be followed, whatever source of such proceedings is or is affected by them. These procedures, chosen by the arbitrator, are not required to be defamatory or to violate the rights and guarantees of the defense and not to prejudice the equality and justice of the opponents (Radwan, Abu Zeid, 1981, p. 101, Abdul Majid, Munir, 1997, p. 251).

\section{First, rules governing the conduct of a dispute in the arbitration of special cases (AD - HOC)}

This method has been followed in some private arbitration participants, such as the arbitration between the Arab American Oil Company, known as Aramco, and Saudi Arabia. Provided in article 4 of the Arbitration Agreement that the rules of procedure to which it is the arbitral tribunal shall be determined by itself, Like the arbitration clause of the Tehran Petroleum Agreements signed in October 1954, which gives the third or the single arbitrator the procedure to be followed in the event that the parties 


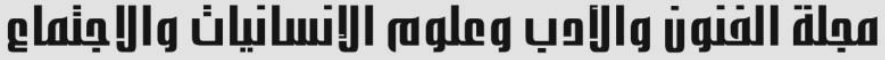 \\ Journal of Arts, Literature, Humanities and Social Sciences www.jalhss.com \\ Volume (54) July 2020 \\ العدد (54) يوليو 2020}

do not agree or disagree on the place and procedures of arbitration (Radwan, Abu Zeid, 1981, p. 101).

This method also recognizes, with regard to the freedom of arbitrators to determine or supplement the procedures for the conduct of the dispute, certain regulations of arbitral tribunals or centers that may be selected by the parties, for example the United Nations Model Rules for Arbitral Procedure and the October 1956 European Economic Commission Regulation of the United Nations; The Court of Arbitration Rules of the Foreign Trade Chamber of Germany, issued in July 1957, the Arbitration Court of the Polish Chamber of Commerce, the Arbitration Rules of the Chamber of Maritime Trade and Foreign Trade of the People's Republic of China, issued in January 1958, and the Danish Arbitration Rules of May 1972.

The International Commercial Arbitration Court states that arbitrators act in this regard with discretion in choosing the rules or law that are most objectively appropriate to the rule of dispute proceedings, either by recourse to the law of the place of arbitration (Radwan, Abu Zeid, 1981, p. 103). Or by choosing procedural rules that are more relevant to the so-called "people's law" than to any other national law, even if it is the law of the place of arbitration, usually in arbitration between States and private foreign companies, and I believe that in this case the law of the place of arbitration should be referred to; Subject to completion of the agreed rules of the parties.

This is consistent with the reference made in the 1958 New York Treaty to the law of the State in which arbitration took place in the absence of an agreement of the parties. The question arises as to what is meant by the law of the place of arbitration is the law of the State in which the arbitral tribunal is convened for the first time or the law of the State in which the arbitral award is made.

I believe that the place of arbitration should be determined from the commencement of arbitration proceedings either on the basis of the agreement of the parties or the place designated by the arbitral tribunal when the parties do not agree (article 20 of the Model Law on International Commercial Arbitration).

International arbitrators have long adopted this trend in the Aramco arbitration judgment on the dispute between the Saudi government and the American Arab Petroleum Corporation (ARAMCO) (Ibrahim, Ibrahim Ahmed, 1997, p. 137), and recently in the arbitration between the Libyan government and Company B. P. British Petroleum, which sentenced the court to Lagergren on October 10, 1973 (Radwan, Abu Zeid, 1981, p. 103).

International arbitrators have long adopted this trend in the Aramco arbitration judgment on the dispute between the Saudi government and the American Arab Petroleum Corporation (ARAMCO) (Ibrahim, Ibrahim Ahmed, 1997, p. 137), and recently in the arbitration between the Libyan government and Company B. P. British Petroleum, which sentenced the arbitrator to Lagergren on October 10, 1973 (Radwan, Abu Zeid, 1981, p. 103).

The arbitrator also concluded the same conclusion in its judgment of 19 January 1977 in the Texaco Ralasiatic case concerning a dispute between the Libyan government 


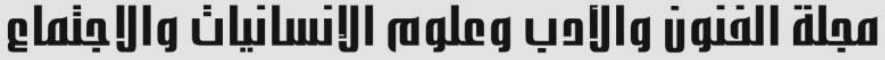 \\ Journal of Arts, Literature, Humanities and Social Sciences www.jalhss.com

and Texaco Overseas for nationalizing its oil companies, although the former company got a contract for oil exploitation in Libyan territory before the revolution. The arbitrator in this case ruled out the application of the law of the State of Arbitration on the grounds that it would facilitate possible implementation because the problem of enforcement should not affect the determination of the applicable law. On the other hand, the jurisdictional immunity of a State required that it should not be subject to the law of another State and concluded that it was the system of arbitration which was determined by law, which required reference to arbitration procedures for the rules of general international law. This also takes into account the fact that the arbitrator has not deviated from the principle of the authority of will, but that principle is enshrined in the provisions of general international law (Ibrahim, Ibrahim Ahmed, 1997, p. 139-140).

This is the conclusion of the Permanent Court of International Justice, which, in the case of loans by Serbs and Brazil, decided that "every contract to which the parties are not States is based is based in domestic law".

This solution is close to what arbitrator Mahmassasani took in his April 12, 1977 ruling in the Liamco case in the dispute between the company and the Libyan government because of its nationalization on February 11, 1974, when the arbitrator decided to give as much credit as possible to the general principles of law regarding arbitration proceedings.

\section{Second: Procedures for the conduct of the dispute before the permanent bodies of international commercial arbitration}

If, as we have seen, the parties to arbitration has a great deal of freedom in the determination of rules or law governing arbitration proceedings before ad-hoc arbitration, whether by drafting a convention for such proceedings or choosing any national law or authorizing arbitrators to do so, However, this arbitration has been less successful in the commercial arbitration of permanent arbitration bodies or centers.

The difficulty that arises when there is no agreement on rules of procedure or the parties are not referring to a law that applies to the arbitrator in the proceedings, as well as in the case of insufficient rules of procedure agreed by the parties, is easily resolved for arbitration under permanent arbitration bodies and centers (Ibrahim, Ibrahim Ahmed, 1997; 134), whether those established by international or collective conventions or permanent centers of an international, qualitative or national character or association, is an organized arbitration in which its due process is settled in the proceedings before an arbitral tribunal or tribunal (Radwan, Abu Zeid, 1981, p. 105).

The parties' reference to the resolution of their dispute or recourse to arbitration shall be considered as an act of acceptance by them of the procedures applied by this body, thus completing the agreed rules of procedure or application by the parties at the time of the agreement of the parties, but these bodies shall have regulations guaranteeing rules of procedure. Whether it is the way in which a court or tribunal is constituted, the choice of arbitrators and the dates set, or those relating to the conduct of the dispute, or even those rules relating to the presentation of evidence and sometimes to 


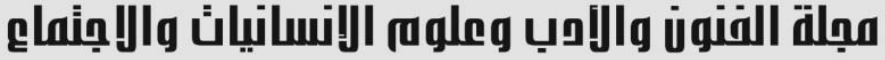 \\ Journal of Arts, Literature, Humanities and Social Sciences www.jalhss.com \\ Volume (54) July 2020 \\ العدد (54) يوليو 2020}

the taking of temporary or preventive action, and how the decision is made in the dispute and its terms (Ibrahim, Ibrahim Ahmed, 1997, p. 134).

In other words, arbitration has become "autonomous law" of procedure so that, with jurisprudence (Radwan, Abu Zeid, 1981, p. 105), it can be said that the parties to the dispute in such arbitration can no longer choose the place of arbitration.

This was embraced by the Convention on the settlement of Investment disputes between States and nationals of other States, concluded on 18 March 1965, article 44 of which deals with "the submission of arbitration proceedings to this treaty unless otherwise agreed by the parties".

\section{2: The authority of the arbitrator to choose the law applicable to the dispute}

When the arbitration dispute has proceeded normally, the arbitrator is obliged to render the judgment whether restricted by law or not (Ibrahim, Ali Salem, 1997, p. 262).

The arbitration dispute begins on the day on which the defendant receives the request for arbitration from the claimant unless the parties agree on another date (article 21 of the Model Law on International Commercial Arbitration).

The arbitrators has wide authority in assessing the facts and settling the dispute, which is in the interest of the opponents, which is what distinguishes arbitration, even if necessary to get out of the logic of the procedural and substantive texts, and it has been rightly said that the ordinary judiciary seeks justice for the benefit of the law, while the arbitrator seeks the law for the benefit of the opponents (Shehata, Mohamed Nour Abd Al Hadi, 1993. P. 362).

Article 31 of the Model Law on International Commercial Arbitration requires that the arbitral tribunal's decision contain the most important data provided by the law for the judgments of the court, not all of which must contain the sufficient amount for the arbitral award to fulfill its function: The signature of arbitrators, the reasons for the judgment, The names, addresses and names of the arbitrators, their addresses, nationality and description, a copy of the arbitration agreement, a summary of the application of the adversaries, their statements and documents, the governing area, the date and place of issuance and reasons for it if it is obligatory to denounce it. The award of the arbitral tribunal composed of more than one arbitrator shall be issued by a majority of views after a deliberation as determined by the arbitral tribunal unless the arbitral party so agrees.

The implementation of the fundamental principles governing the judicial dispute by the arbitral tribunal is not sufficient in itself to achieve all the objectives of organizing and resorting to arbitration, including economy at the time and expense, Before addressing the dispute before it, the arbitral tribunal must also take into account certain matters, otherwise the fate of its invalidity decision would be: The availability of the authority to adjudicate the dispute before it must be ascertained, the deadlines for the filing must be respected, the date on which the dispute arose must be determined, the character and full eligibility of the adversaries must be verified and the arbitral tribunal must be committed to the scope of the arbitration dispute 


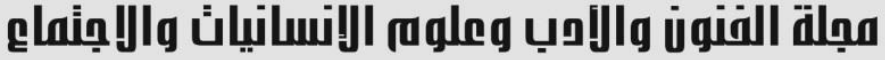 \\ Journal of Arts, Literature, Humanities and Social Sciences www.jalhss.com \\ Volume (54) July 2020 \\ العدد (54) يوليو 2020}

(Mabrouk, Ashour, 1988, p. 237).

One of the most important arbitration cases, the law is applicable to the subject of the dispute, which is the basis for the award of arbitration, and thus the resolution and termination of the dispute.

The majority of legal systems have respected the will of the arbitrators, whether in choosing the rules or the law directly governing the subject of the dispute or in referring them to the rules of the dispute of a particular State in the light of which those rules are determined, or by giving the arbitral tribunal the authority to choose appropriate or appropriate rules.

However, the difficulty arises in the absence or failure of this will to specify the rules or law that will govern the dispute so that the conduct or contract will be silent on this issue.

It may be useful to say that this silence may be due to the disregard or ignorance of the arbitrators of this important issue, or to their deliberate deliberate attempt to avoid entering into a controversial issue that may lead to the failure of contracting, leaving discussion of these issues for another time, or authorizing the arbitrator to carry out this task.

Therefore, we will identify the freedom of the arbitrators to determine the law applicable to the dispute and the authority of the arbitrator to choose the applicable law, and the criteria on which this search for law is based the duty to apply to the subject matter of the dispute.

\section{1: The treaty character of the arbitrators in determining the law applicable to the subject of the dispute}

The majority of national legislations ${ }^{(2)}$ and international arbitration conventions established the principle of the authority of will in determining the law that is applicable to the subject of dispute in the arbitration dispute, which is one of the most important distinguishing features of arbitration and which leads the parties to the dispute to leave the ordinary courts and resort to arbitration as an alternative way. The freedom of the parties to choose the law applicable to their dispute and the obligation of the arbitrator to abide by what the parties have agreed to, and not to derogate from or exceed it is of the utmost importance in the arbitral process, and there is nothing preventing the procedure and the subject of the dispute from being subject to the same law. They may also be subject to two different laws or several laws as agreed by the parties to the conflict, but the positive role, as some of them believe, is that (Abdurrahman, Huda Muhammad, 1997, p. 267) is not absolute, and it must not be so, because the will of the parties whose existence derives from the legal system that has been recognized and defined, and comes at the forefront of controls restricting the freedom of the parties to a dispute to choose the applicable law, the need for a link between the law and the contract under which the dispute arose, The freedom of the parties found its limits in basic and fundamental rules to define the legal system of the State and, in general, jus cogens and public order.

This is understood in the text of article (28/1) of the Model Law on International 


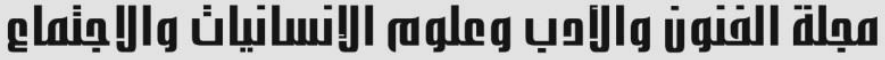 \\ Journal of Arts, Literature, Humanities and Social Sciences www.jalhss.com \\ Volume (54) July 2020 \\ العدد (54) يوليو 2020}

Commercial Arbitration, in which the arbitral parties were given full freedom to choose the rules applicable to the subject matter of the dispute by stating that: "The arbitral tribunal shall decide the dispute in accordance with the rules of law chosen by the parties as applicable to the subject matter of the dispute, Any choice of the law or legal system of a State must be taken as a direct reference to the substantive law of that State and not to its rules of conflict of law, unless otherwise expressly agreed by the parties".

\section{2: The authority of the arbitrator to choose the law is applicable to the subject matter of the dispute}

The majority of legal systems have respected the will of the parties with regard to their choice and enforcement of the legal rules governing the subject matter of the dispute, whether express or implied, as long as they do not violate the public order of the competent State, and as long as the choice is not distorted by the law that was supposed to govern the dispute.

However, there is a difference in the various legal systems over the limits to which the authority of will exists because the parties have not defined the law applicable to the subject of the dispute and, therefore, it is necessary for the arbitral tribunal to resort in its search for rules of conflict of law to reach the applicable law to five criteria: Place of arbitration, place of contract signature, place of residence of the parties to the contract and country of execution of the contract, language of the contract or arbitration if the contract is selected as a language and arbitration is another language ${ }^{(3)}$.

With reference to the provisions of Bahraini law, article 28 of the Model Law on International Commercial Arbitration stipulates that:

"2. If the parties have not appointed any rules, the arbitral tribunal shall apply the law established by the conflict of laws rules which the Commission considers applicable. 3. The arbitral tribunal shall not adjudicate the dispute on the basis of respect for justice and the person, or as a fair and equitable arbitrator, unless expressly authorized by the parties. 4. In any event, the arbitral tribunal shall adjudicate the dispute in accordance with the terms of the contract, taking into account the customs applicable to that type of business activity applicable to the transaction" (4).

Thus, it is clear that the authority of the arbitrator to choose the applicable law is reserve in nature and only when there is no agreement between the adversaries on the determination of the applicable law, and that the exercise of that authority shall be restricted to any restrictions agreed upon by the arbitrators to the extent that they do not conflict with jus cogens (Rules of public order in the State) ${ }^{(5)}$.When left to choose the applicable law, the arbitral tribunal must take into account the law most relevant to the subject matter of the dispute, that is, the criterion is objective, not personal, and is not absolute, but there are disciplines and criteria that are to be taken into account when the body chooses this law. Its choice may fall on the law applicable to the contract as being best for the adjudication of disputes arising in connection with the contract under which it was concluded, which may be the law of the place of 


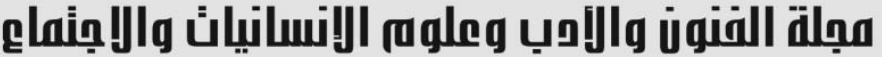

Journal of Arts, Literature, Humanities and Social Sciences www.jalhss.com

Volume (54) July 2020

العدد (54) يوليو 2020

arbitration, the choice may be in accordance with the rules of dispute, and the most appropriate law may choose among the laws nominated by the rules of dispute.

\section{Conclusion:}

The study examined the legal scope of the arbitrator's authority to resolve disputes arising in civil and commercial transactions which the parties agree to resolve by arbitration. Arbitration constituted a firm fact and an inescapable reality that contributed significantly to the resolution of disputes, both national and international. However, the use of arbitration as a means of resolving disputes is hampered by a number of obstacles, the most important of which is the law applicable to the dispute, from the arbitration agreement to the arbitral award issued. The law chosen, whether chosen through the will of the parties, through the arbitrator or by the legislative rules, also has the general objection that the law applicable to public order in the country in which the provision is to be recognized, through this study has reached several conclusions and recommendations.

\section{First: Results}

1. It is clear from the Bahraini Arbitration Act and the UNCITRAL Municipal Model Law", comparative legislation, international treaties and conventions, and arbitration provisions that they give priority to the will of the parties to establish the proceedings themselves, to choose a national law or an arbitration regulation to apply to the proceedings. In the absence of such an agreement, the arbitral tribunal shall have the authority to choose the applicable law according to the alternatives referred to in the examination research.

2. The authorities of the arbitrator stem from the arbitration agreement, as well as from the authorities vested by the legislator under the arbitration law, which start from the establishment of the procedural system of arbitration, by setting dates, reporting, managing and organizing hearings, and determining the language of arbitration through the procedural rules applicable to the dispute and applicable law, and the procedures of proof; Termination, correction and interpretation of the arbitral award, and award of applications not covered by the arbitral award and the award was closed down.

3. In the context of the arbitration dispute, the arbitrator has broad authorities with a view to issuing his judgment quickly and effectively, although he lacks the authority of order and force of the judge, these broad authorities are not unlimited, but rather impose obligations on the arbitrator, whether legal obligations or a convention.

4. The failure of the parties to agree on a particular law to govern their contractual relationship raises the problem of the breach of the expectations of the parties because of the application of an unagreed law governing their contractual relationship.

5. The main difference between the laws is the duty to apply to arbitral proceedings and that which is applicable to the subject matter of the dispute. That the law applicable to the proceedings is not an end in itself, but a means used to reach a 


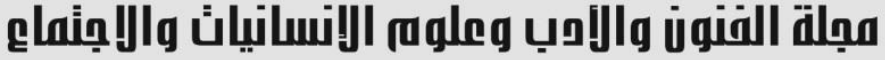 \\ Journal of Arts, Literature, Humanities and Social Sciences www.jalhss.com \\ Volume (54) July 2020 \\ العدد (54) يوليو 2020}

particular purpose of demonstrating the disputed aspects of the truth among the arbitrators before the arbitrators who adjudicate it, While the law governing the subject of the dispute embodies the rights and obligations of the parties to define and define these rights and obligations, it is an end in itself.

6. The issue of applicable law in the arbitration case in general is of great importance, as it is the procedural rules that will govern the conduct of the litigation from procedures such as dates, exchange of notes and documents, hearing witnesses, causing and filing of the judgement, etc., and there is no doubt that the observance of these rules in a manner It is true that a valid arbitration judgement that can be recognized and implemented would be reached, and on the contrary, a violation of these rules would open the door wide open to challenging the arbitral award of nullity and refusing to recognize it and implement it, As for the law applicable to the subject of the dispute, the future of the dispute is dependent on its determination of the rules and provisions in which the rights, obligations and fate of all the arbitral disputes will be determined.

7. In view of the importance of the determination of the law applicable to the subject of the dispute, the various legal regimes for arbitration have paid much attention to the legal regulation of the arbitration system in general and the determination of the law applicable to the subject matter of the dispute in particular.

8. The fact that the laws and regulations on arbitration are based on the fact that there are mostly common rules, and that most of them have an important legal principle of the freedom of the arbitrators to choose the law governing the proceedings, which governs the subject of the dispute. The search for the law governing the procedure or that governing the subject matter of the dispute day by day emphasizes the international nature of this system as an independant judiciary of international trade, and it is now almost universally enjoyed by an independent law governed by it.

9. The arbitrator's task in the dispute over arbitration shall expire with the issuance of the arbitral award, which is the natural end of his or her mission, and his or her task may pass in an early manner, that is, without the completion of his or her task, and the expiration of the arbitrator's function may be an effect of the termination of the arbitration proceedings.

\section{Second: Recommendations}

1. The legislator recommended that the authorities of the arbitrator be clearly defined before the dispute occurs and be defined as widely as possible, so as to face any problems that the parties to the dispute may encounter during the course of the arbitration dispute.

2. When the arbitral tribunal leaves it to the question of the choice of applicable law, it must take into account the law most relevant to the subject of the dispute, since the criterion is objective and not personal, freedom is not absolute to it, but there are controls and standards to be taken into account when choosing The commission of this law, may be chosen on the applicable law on the contract being the best on the 


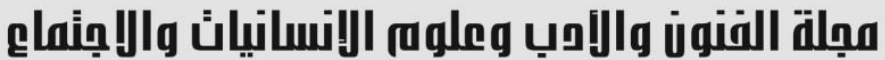

Journal of Arts, Literature, Humanities and Social Sciences

www.jalhss.com

judgment of disputes that arise in relation to the contract under which it was concluded, and this may be the law of the place of arbitration, and the choice may be according to the rules of conflict, and here you may choose the most appropriate law among the laws nominated by the rules of conflict.

3. An additional reason for accepting an action to revoke an arbitral award is that the arbitral tribunal does not comply with the law applicable to the subject matter of the arbitral dispute.

4. The legislator recommended that legal provisions be drawn up in the Arbitration Act governing the civil liability of the arbitrator for his or his wrong actions.

\section{Margins}

(1) Published in Official Gazette No. 3217, dated 9.7.2015, p. 109.

(2) Article 36/1) Jordanian Arbitration, Chapter 73 of the Tunisian International Arbitration Act, article 458 bis 14 of the Algerian International Arbitration Act, article 39 Omani arbitration, article 45 Yemeni arbitration.

(3) See the judgment of Arbitration in case No. 95 of 1997, 12.3.1998, before the Cairo Regional Center for International Commercial Arbitration, published in the Arab Arbitration Journal, No. 1, May 1999, item 7, p. 151.

(4) See also Bahraini Court of Cassation decision No. 507 of 2008, 27.4.2009, rule 104, p. 435.

(5) See the judgment of Arbitration in case No. 51 of 2000, meeting in 8.6.2000, before the Cairo Regional Center for International Commercial Arbitration, published in the Arab Arbitration Journal, No. 3, October 2000, item 12, p. 210. 


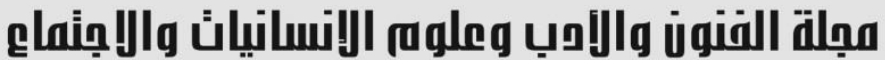

Journal of Arts, Literature, Humanities and Social Sciences

www.jalhss.com

\section{References}

1. Abdul Majid, Munir. (1997). The legal organization of international and domestic arbitration in the light of jurisprudence and arbitration. Alexandria: Knowledge facility.Abdul Rahman, Huda Mohammed. (1997). The role of the arbitrator in the arbitration dispute and the limits of his authorities. Cairo: Arab Renaissance House.

2. Abu Al-Ala Ali, Abu Al-Ala. (N.D). The law is applicable to procedural matters in the field of arbitration. First Edition. Cairo: Arab Renaissance House.

3. Alhadad, Hafeza Alsayed. (1997). Challenge the invalidity of arbitral awards in international private disputes. Alexandria: University thought House.

4. Alrefeay, Ali Kazim. (N.D). Authorities of the International Commercial arbitrator. Baghdad: Faculty of Law.

5. Haddad, Hamza, (1989). Arab agreements for commercial arbitration. A publication was discussed at the Third Conference of Arab-European Arbitration. Amman.

6. Ibrahim, Ibrahim Ahmed. (1997). Special international arbitration. Second edition. Cairo: Arab Renaissance House.

7. Mabrouk, Ashour (1998). Procedural system of arbitration dispute. Second edition. Mansoura: The new library of evacuation.

8. Radwan, Abu Zeid. (1981). General grounds in international commercial arbitration. Cairo: Arab thought House.

9. Shehata, Mohamed Nour Abd Al-Hadi. (1993). The Convention was established by the judicial authorities of the arbitrators. Cairo: Arab Renaissance House. 